\title{
TARİHİ YAPILARDA KULLANIM DÖNÜŞÜMÜNÜN SOSYAL BOYUTU ; BAĞLARBAŞI ELEKTRİK FABRIKKASI VE TRAMVAY DEPOSU ÖRNEĞİ
}

\author{
HasanTASTAN ${ }^{1}\left(\right.$ ORCID: 0000-0002-9440-051X)* $^{*}$ \\ Kunter MANISA ${ }^{1}$ (ORCID: 0000-0002-8209-0905)
}

${ }^{I}$ Mimarlık Bölümü, Yıldız Teknik Üniversitesi, İstanbul, Türkiye

Geliş/Received: 30.11 .2018 Kabul / Accepted: 27.05.2019

\begin{abstract}
ÖZ
Tarihi yapılar geçmişe ait yapım teknikleri, malzeme özellikleri ve sosyo-kültürel değerler gibi birçok bilgiyi ve tarihsel hafizayı günümüze taşırlar. Zaman içerisinde değişen yaşam koşullarının bir sonucu olarak çoğu tarihi yapı özgün işlevini devam ettiremez hale gelmektedir. Tarihi yapıların taşıdıkları değerin sonucu olarak, yeniden kullanılmaları sadece çevresel ve ekonomik olarak değil aynı zamanda sosyal ve kültürel olarak da fayda sağlamaktadır. Bu çalışma kapsamında Üsküdar'da yer alan Bağlarbaşı Elektrik Fabrikası ve Tramvay Deposu'nda gerçekleştirilen kullanım dönüşümü süreci sosyo-kültürel sürdürülebilirlik bağlamında değerlendirilmiştir. Çalışmada öncelikle yapılan literatür araştırması ile sosyal sürdürülebilirlik ölçütleri belirlenmiştir. Çalışmanın ikinci aşamasında yapı ve yakın çevresi üzerine yapılan analizler ile öngörülen ölçütlerin yerine getirilip getirilmediği tartışılmıştır. Çalışmanın sonuç kısmında ise gelecekteki yeniden kullanım çalışmalarına yardımcı olacağı düşünülen çıkarımlar yapılmıştır. Tarihi yapıların çoğunun kentsel alanda merkezi bir konumda yer aldığı göz önüne alındığında yapıdan toplumun tüm katmanlarının faydalanabilmesi için yapıya kamusal, geniş kesimlere hitap eden bir fonksiyon verilmesi ve kamu tarafından işletilmesinin uygun olacağı yapılan çıkarımlardan bazıları olmuştur.
\end{abstract}

Anahtar kelimeler:Kullanım dönüşümü, sosyal sürdürülebilirlik, tarihi yapılar, kültürel süreklilik, endüstri miras1

\section{SOCIAL DIMENSION OF THE ADAPTIVE REUSE OF HISTORIC BUILDINGS; THE EXAMPLE OF BAĞLARBAȘI ELECTRIC FACTORY AND TRAM DEPOT}

\begin{abstract}
Historical structures carry many data such as construction technologies, material properties and socio-cultural values to the present day. As a result of time-varying living conditions, most historical buildings are unable to maintain their original function. The reuse of historical buildings with the value they carry is not only environmental and economical but also socially beneficial.In the context of this study, the reuse process of Bağlarbaşı Electric Factory and Tram Depot was evaluated in the context of socio-cultural sustainability.In the study, first of all, social sustainability criteria were determined by the literature research.In the second phase of the study, the analyzes on the structure and its close surroundings were discussed and it was discussed whether the criteria determined in the first stage were met.In the conclusion part of the study, the implications that are expected to be helpful in future re-use studies have been made.Considering the fact that most of the historical buildings are located in the city center, some of the inferences are given to the public to provide a function to the public and to be operated by the public.
\end{abstract}

Keywords: Adaptive Reuse, social sustainability, historical buildings, cultural continuity, industrial heritage

${ }^{*}$ Corresponding author / Sorumlu yazar. Tel.: 02123832603 ; e-mail / e-posta: hasantastan88@ hotmail.com 


\section{GíRiş}

Kentler kuruldukları zamanlardan günümüze kadar geçen süre içerisinde fiziksel ve sosyal olarak sürekli değişim halinde olmuşlardır. Kent hayatının önemli bir parçası olan yapılı çevre insan eli ile oluşturulmakta ve kendisini oluşturan toplumun yaşadığı sosyal ve ekonomik değişimlerden etkilenmektedir. Yapılı çevrenin geçirdiği bu değişim doğal olarak toplumsal dinamikleri etkilemekte yaşanılan çevrenin niteliği gelecek nesillerin yaşam kalitesini belirlemektedir. İnşa edildikleri dönemin kültürünü ve kimliğini günümüze taşıyan tarihi yapılar malzeme, yapım teknikleri ve mekân organizasyonları gibi özellikleri ile bulunduğu yapılı çevrenin ve toplumun geçirdiği değişimi göstermektedir. Tarihi yapılar bu özellikleri ile toplumların varlıklarını devam ettirebilmeleri ve kültürlerini gelecek nesillere aktarabilmeleri için gerekli altyapıyı sağlamaktadır. Kentte toplumun kimliğini yansıtan, geçmiş dönemlere ait izler taşıyan tarihi yapılar korunması ve gelecek nesillere aktarılması gerekli kültür varlıklarıdır. Ancak her yapı gibi tarihi yapılar da zaman içerisinde değişen koşullara bağlı olarak özgün işlevlerini yerine getiremez hale gelebilmektedirler. Böyle bir durumdaki yapıya uygun işlevler vermek ve müdaheleler ile kullanım dönüşümügerçekleştirmek tercih edilen bir yöntemdir. Çünkü yapıyı zamanda dondurarak pasif bir şekilde varlığını devam ettirmek ise yapının fiziksel olarak varlığını devam ettiren ancak yapının topluma etkili şekilde hizmet etmesini engelleyen bir koruma yöntemidir. Bunun yerine yapıya yeni bir işlev vermek ve insanlar tarafından kullanılmaya devam edilmesini sağlamak hem tarihi yapının taşıdığı değerleri günümüze taşıyacak hem de insanların kullanımına sunulmadan, sadece korunması ile oluşan emek ve enerji sarfiyatının önüne geçecektir.

Son yıllarda kullanımı giderek yaygınlaşan “Adaptive reuse” kavramı ilk olarak 1994 Brownfield örneğinde kentsel sağlıklaştırmanın (rehabilitation) bir aracı olarak ortaya atılmış bir kavramdır. "Uyabilen yeniden kullanım" olarak Türkçe'ye çevrilebilecek kavram; Eski bir binanın veya yerleşim yerinin yapılma ve tasarlanma amacından farklı olarak kullanılması işlemini tarif etmek için kullanılmaktadır. Amerika Birleşik Devletleri, Massachusetts, Brownfield'de 1994 yılında yapılan kentsel ıslahdan sonra "adaptive-reuse" arazi ıslahındakorunmasında ve kentsel yayılmanın engellenmesi konusunda önemli bir faktör olarak görülmeye başlanmıştır. Ancak renovasyon ve adaptive-reuse arasında bulanık bir çizgi vardır, bu nedenle kavram tarihi yapıların korunması ve yıkımı arasında bir uzlaşı noktasındadır [1]. Bu bağlamda metin içinde ifade edilen "Yeniden kullanım”ve "kullanım dönüşümü” ifadeleri“adaptive reuse” teriminin karşılığı olarak kullanılmıştır.

$\mathrm{Bu}$ çalışmanın amacı tarihi yapılara uygulanan kullanım dönüşümü projelerinin sosyal sürdürülebilirlik bağlamında içerdiği riskleri ve firsatları ortaya koymaktır. Bu kapsamda 1.Ulusal Mimarlık Akımı özellikleri taşıyan Üsküdar Bağlarbaşı Elektrik Fabrikası ve Tramvay Deposu'nun kafe-kütüphane olarak yeniden işlevlendirilme süreci, çevresel, ekonomik ve sosyo-kültürel sürdürülebilirlik bağlamında değerlendirilmiştir. Kullanım dönüşümü uygulamalarında geriye dönük adım atmanın zorluğu bu çalışmanın yapılmasını tetikleyen sebeplerden biri olmuştur.

Mevcut yapının yeniden kullanımı için yeni işlevin seçimi, yapılacak müdahalelerin kapsamı gibi kararlar, uzun araştırmaların ve gözlemlerin yapıldığı bir sürecin sonucunda alınmalıdır. Bu bağlamda daha önce gerçekleştirilmiş projelerden edinilen tecrübeler ve alınan dersler sonraki çalışmalar için yol gösterici olacaktır. $\mathrm{Bu}$ çalışma ile elde edilen sonuçların gelecekte yapılacak kullanım dönüşümü projelerine katkı sağlanması hedeflenmektedir.

Çalışmada öncelikle yapılan literatür araştırması ile sürdürülebilir gelişme paradigmasının ölçütleri belirlenmiştir. Mimaride kullanım dönüşümünün çevresel ve ekonomik faydalarının ortaya konmuştur. Daha sonra ise sosyal sürdürülebilirlik literatüründen yeniden kullanım ile ilişkili olduğu düşünülen ölçütler derlenmiştir. Seçilen ölçütler Bellek, Kimlik, Aidiyet, Yaşam Kalitesi, Mekân Hissi, Fiziksel ve Psikolojik Konfor, Adalet, Eşitlik, Katılım, Çevresel Kalite, Sosyal Fayda, Topluluk Hissi olmuştur. Çalışmanın sonucunda yapı ve yakın çevresi üzerine yapılan analizler ile ilk aşamada belirlenen ölçütlerin yerine getirilip getirilmediği tartışılmıştır. Ölçütlerin ne ölçüde yerine getirildiği kullanım dönüşümünün boyutunu ifade eden üç önemli aktörün yani Kent ve Kentli, Dönüştürülen Yapı ve Yapıya Verilen Yeni İşlev 'in kullanım dönüşümünden nasıl etkilendiği üzerinden yapılmış, yapılan değerlendirmeler ile gelecekteki kullanım dönüşümü çalışmalarına yardımcı olacağı düşünülen çıkarımlar yapılmıştır.

\section{MIMARIDE KULLANIM DÖNÜŞÜMÜ KAVRAMI}

Mimaride kullanım dönüşümü ya da yeniden kullanım, herhangi bir sebeple özgün işlevini yerine getiremez hale gelen yapının başka bir işlevi yerine getirecek şekilde yeniden düzenlenmesi olarak tanımlanmaktadır. Kullanım dönüşümü mevcut yapıyı olabildiğince korurken, günümüz kullanıcı gereksinimlerine cevap verebilecek şekilde geliştirildiği bir süreçtir [2]. Kullanım dönüşümü uygulamalarında herhangi bir sebeple özgün işlevini yerine getiremeyen, yakın zamana ait bir yapı olabileceği gibi söz konusu yapı tarihi değer de taşıyor olabilir. Yapının tarihi olması, endüstri mirası veya kültürel miras özelliği göstermesi yeniden kullanımın 
getireceği faydaları da artıracaktır. Özellikle sanayi devrimi ile ortaya çıkan endüstri yapıları, aradan geçen süre içerisinde üretim tekniklerinin değişmesi, hızlı kentleşmeye bağlı olarak yapının kent merkezinde kalması gibi sebeplerle atıl hale gelmişlerdir. Endüstri mirası özelliği taşıyan bu yapıların kullanım dönüşümü uygulamaları ile yapıların kimlikleri korunurken farklı bir işlevle de olsa yaşamaya ve topluma hizmet etmeye devam etmeleri sağlanmaktadır. Tarihi ve kültürel değer taşıyan yapıların yaşatılması, günümüz ihtiyaçlarına cevap verebilecek hale getirilerek değerlerine değer katılması sürdürülebilirlik tartışmaları bağlamında da olumlu bulunan ve tercih edilen bir yöntemdir. Kent dokusu içerisinde atıl bir şekilde yer alan tarihi bir yapının yeniden kullanılması, ona yeni bir işlev vererek otantik değerinin ortaya çıartılarak çekim noktası haline getirilmesi yapının yakın çevresinin de iyileştirilmesi ve canlandırılması için bir firsat sunmaktadır.

\subsection{Kullanım Dönüşümü ve Sürdürülebilirlik Paradigması}

Gelecek kuşakların kendi ihtiyaçlarını karşılama gücünü tehlikeye atmadan günümüz kuşaklarının ihtiyacının karşılanması ve gelişmenin devam ettirilmesi anlamına gelen sürdürülebilir gelişme kavramı günümüzde her alanda olduğu gibi mimarlık alanında da politikalara yön veren önemli bir tartışma konusudur. Kavramın ortaya çıkışından günümüze kadar geçen sürede çeşitli tanımlamalar ve sınıflandırmalar yapılmıştır. Ancak günümüzde sürdürülebilir gelişme tartışmalarındaki ortak düşünce sürdürülebilirliğin sosyal, ekonomik ve çevresel olmak üzere üç ana boyutu olduğu ve bunların birbirleri ile bir şekilde ilişkili olduğu yönündedir [3]. Sürdürülebilir gelişme anlayışının mimarlık alanına yansımaları bu üç boyutta çeşitli kavramların öne çıkması ile olmuştur. Gelişmenin çevresel ve ekonomik boyutu düşük enerji tüketimi, geri dönüşümlü malzeme kullanımı ile öne çıkarken sosyal boyutu yaşam kalitesinin artırılması, toplumsal kaynaşmanın sağlanması gibi konulara odaklanmıştır.

Kullanım dönüşümü uygulamaları sürdürülebilirliğin ekonomik, sosyal ve çevresel boyutları için çeşitli firsatlar barındırmaktadır. Son yıllarda modern yapım tekniklerinin kullanımının yaygınlaşması ve malzeme çeşitliliğin artması ile başarılı kullanım dönüşümü uygulamalarının sayısı da artmıştır. Atıl durumdaki yapıların yeniden değerlendirilmesi ile topluluk için yeni kaynaklar yaratılabilmekte, yapılı çevrenin daha kaliteli hale getirilmesi ile toplumun refah seviyesi yükseltilmektedir. Kullanım dönüşümü ile arazi ve inşaat maliyetleri önemli ölçüde azalırken, mevcut kent parçalarının canlandırılması ve dağınıklığın kontrol altına alınması mümkün olmaktadır. Ayrıca kullanım dönüşümü kaynak tüketimi, enerji kullanımı ve zararlı gaz salınımlarının azaltılması, binaların ömrünün uzatılması, arazi tüketiminin ve kentsel yayılımın azaltılması gibi çevresel faydalar sağlamaktadır [4]. Kullanım dönüşümünün bir diğer faydası da mevcut binalardan yararlanarak, yapılı çevreyi estetik açıdan daha hoş ve üretken kılma olanağı sağlanmasıdır [5]. Böylece yapılı çevrenin estetik çekiciliğini artırılarak, mevcut semtlerin yeniden canlandırılması verimsiz mülklerden değerli topluluk kaynakların yaratılması mümkün olmaktadır. Kullanım dönüşümü ile mekân hissi uyandıran sokak dokusunun ve kültürel mirasın korunması, mevcut yapıların korunması talebini artırmakta, toplumda tarihi değerlerin korunması için farkındalık oluşturmaktadır [4]. Çevredeki tarihi yapıların sağladığı mekân hissi bireylerin korunması gerekli tarihi yapılara karşı daha bilinçli ve duyarlı olmalarını sağlamaktadır. Bu bağlamda kullanım dönüşümünün ekonomik, çevresel ve sosyal faydalar sağladığı ortadadır. Dönüştürülen yapının tarihi özellik taşıması getirdiği sosyal faydaları daha da artıracaktır.

\subsection{Tarihi Yapılarda Kullanım Dönüşümü Uygulamalarının Riskleri ve Zorlukları}

Tarihi yapıların yeniden yaşayan mekânlar haline getirilmesinde yenileme ve koruma çalışmalarının yanı sıra kullanım dönüşümü uygulamaları da giderek önem kazanmaktadır [6]. Başarılı bir kullanım dönüşümü uygulaması yeni ve eski arasındaki ilişkiyi en iyi şekilde kurmalı, yapım tekniği malzeme gibi yapının özgün niteliklerini korumalıdır. Bunu yaparken aynı zamanda yapıyı günümüz ihtiyaçlarına cevap verebilecek hale getirmeli değerine değer katmalıdır. Kullanım dönüşümünde yapının sürdürülebilirliğinin sağlanması için öncelikli konulardan biri yeni işlevin doğru seçilmesidir. Yapıya yüklenecek işlev mevcut mekânsal düzeni ile uyumlu olmalı, kentlinin ihtiyaçlarına cevap verecek nitelikte olmalıdır. Yeni işlevin belirlenmesinde mevcut yapının mekânsal organizasyonu, yapım tekniği ve malzeme özellikleri analiz edilmeli yapıya verilmek istenilen yeni işlevin uygunluğu değerlendirilmelidir [7].

Tarihi yapıya yeni işlev verilirken sadece yapının kendisi değil bulunduğu bölgenin karakteristikleri de göz önünde bulundurulmalıdır. Başarılı bir kullanım dönüşümü uygulaması, yapının bulunduğu bölge fiziksel, sosyal ve kültürel olarak canlandırılması ile mümkün olacaktır [8]. Tarihi yapılardakullanım dönüşümü sosyal, çevresel ve ekonomik olarak birçok fayda sağlasa da, aktörlerin çeşitliliği ve yapılacak farklı uygulamaların getirdiği bazı riskler mevcuttur. Bina sahipleri, kullanım dönüşümünde hiçbir ekonomik fayda görmüyor olabileceği gibi tarihi yapıya kapsamlı ve pahalı yenileme gerekebilir. Yenilemenin maddi boyutunun yanında çeşitli teknik sorunlar da çıkabilir. Eski binalar mevcut sürdürülebilirlik standartlarını karşılayamayabilir ya da binanın yapısal bütünlüğünü korumak zor olabilir [4]. 


\subsection{Kullanım Dönüşümü ve Sosyal Sürdürülebilirlik Ölçütleri}

Sürdürülebilir gelişmenin sosyal boyutunu ifade eden sosyal sürdürülebilirlik çeşitli çalışma alanlarını kapsayan oldukça geniş kapsamlı bir kavramdır. Farklı disiplinlerden araştırmacılar kavram ile ilgili sınıflandırmalar ve tanımlamaların yanı sıra sosyal sürdürülebilirliğin nasıl değerlendirilebileceğine yönelik çalışmalarında çeşitli ölçütler belirlemişlerdir. Temel ihtiyaçların karşılanması, fiziksel ve psikolojik konfor ve eşitlik - adalet gibi üst başlıkları ifade eden ölçütlerden bazıları; demokrasi, katılım, eşitlik, dayanışma, topluma katılım, topluluk hissi, aidiyet, mekan hissi, sosyal kaynaşma, toplumsal istikrar, yaşam kalitesi, çevresel kalite, erişebilirlik, kamusal alan, istihdam, temel ihtiyaçların karşılanması, güvenlik hissi, eğitim, sağlık, temel servislere adil erişim olarak sıralanabilir [9].

$\mathrm{Bu}$ çalışmada Üsküdar Bağlarbaşı Elektrik Fabrikası ve Tramvay Deposu'nda gerçekleştirilen kullanım dönüşümünün sosyal sürdürülebilirlik ölçütleri açısından değerlendirilmesi amaçlanmaktadır. Bu bağlamda dönüşüm esnasında gerçekleştirilen yenileme projesinin ve diğer teknik konuların uygulanış şekline bakılmamış, kullanım dönüşümünün sosyal ve kültürel etkisi ele alınmıştır. Çalışmada öncelikle sosyal sürdürülebilirlik literatüründe yer alan ölçütlerden oluşan bir ölçüm tablosu oluşturulmuştur. Literatürde yapılı çevre- insan ilişkisinin sonucu ortaya çıkan olumlu ölçütler Kent ve Kentliler, Dönüştürülen Yapı ve Yeni İşlev olmak üzere üç ana bileşenin etkileşimini ifade edecek şekilde bir araya getirilmiştir (Tablo 1). Kullanım dönüşümünde birbirini etkileyen bu üç ana aktör ve bu aktörlerin birbirlerini etkileme şekilleri projenin ne ölçüde sosyal olarak sürdürülebilir olduğunu belirlemektedir.

Tablo 1. Kullanım dönüşümünde aktörler ve sosyal sürdürülebilirlik Ölçütleri

\begin{tabular}{|c|c|c|}
\hline Etkilenen Aktör & Gerçekleştirilen Faaliyet & Sağlanan Ölçüt \\
\hline \multirow{3}{*}{$\begin{array}{l}\text { Dönüştürülen } \\
\text { Yapı }\end{array}$} & Yapının karakteristik özelliklerinin korunması. & Bellek, Kimlik, Aidiyet \\
\hline & $\begin{array}{l}\text { Yapının dönüştürüldükten sonra özgün işlevine ilişkin izlerin } \\
\text { (mekansal özellikler-donamımlar-eskimişlikler vb.) varlığı ve } \\
\text { korunmuşluğu. }\end{array}$ & Bellek, Kimlik, Aidiyet \\
\hline & Yapının efektif kullanımı, Yaşamaya devam etmesi & Bellek, Kimlik, Aidiyet \\
\hline \multirow[t]{5}{*}{ Yeni İşlev } & Yapının yeni işleve yapısal olarak uygunluğu. & Yaşam Kalitesi \\
\hline & Yeni işlevin gerektirdiği mekânsal ihtiyaçların karşılanması. & Mekân Hissi \\
\hline & $\begin{array}{l}\text { Yeni işlevin gerektirdiği fiziksel ve psikolojik konforun } \\
\text { sağlanmasi. }\end{array}$ & $\begin{array}{l}\text { Fiziksel ve Psikolojik } \\
\text { Konfor }\end{array}$ \\
\hline & Mekânsal erişilebilirlik & Adalet, Eşitlik \\
\hline & Yeni işlevin belirlenmesinde katılımcılık & Katılım, Aidiyet \\
\hline \multirow[t]{5}{*}{ Kent ve Kentli } & Yakın çevresi ile fiziksel uyum & Çevresel Kalite \\
\hline & Kent ve kentlinin ihtiyaçlarını karşılama & Sosyal Fayda \\
\hline & Kente sosyal ve ekonomik katkı sağlama & Sosyal Fayda \\
\hline & Kent imajına ve kimliğine katkı sağlama & Topluluk Hissi, Kimlik \\
\hline & Kullanıcı memnuniyeti & Yaşam Kalitesi \\
\hline
\end{tabular}

Kullanım dönüşümü uygulanacak tarihi yapı toplumun kimliğinin ve belleğinin bir parçasıdır. Tarihi yapı geçmiş ile kurduğu bağlar ile bireylerde aidiyet duygusunun gelişmesini sağlar. Bu nedenle kullanım dönüşümü sırasında yapılacak müdahalenin kapsamı önem taşımaktadır. Kullanım dönüşümü sonrasında yapının malzeme, strüktür gibi karakteristik özellikleri ve özgün işlevine dair izler korunmalıdır.

Yapıya verilen yeni işlevin kullanıcılar tarafından benimsenmesi ve yeni işlevin gerektirdiği fiziksel ihtiyaçların yapı tarafından karşılanabilmesi gerçekleştirilen dönüşümün başarısını etkilemektedir. Başarılı bir uygulama mekân hissinin oluştuğu, erişilebilir ve kapsayıcı, kullanıcının fiziksel ve psikolojik ihtiyaçlarını karşılayan kısaca toplumun yaşam kalitesini artıran niteliklere sahip olmalıdır.

Başarılı bir kullanım dönüşümü uygulamasından bahsedebilmek için öncelikle dönüştürülen yapının kente ve kentliye sosyal, ekonomik ve çevresel olarak katkı sağlaması, kentin ihtiyaçlarını karşılaması gerekmektedir. Bu bağlamda dönüştürülen tarihi yapı kent imajına ve kimliğine katkıda bulunarak topluluk hissini artırabilir. Yakın çevresi ile uyum içinde olup bir odak noktası haline gelerek çevresel kalitenin artırılmasını sağlayabilir.

Tarihi yapıların genellikle şehir merkezlerinde yer alması ve tüm kentli için ulaşım açısından erişilebilir olmaları yapının yeniden kullanılması için firsat sunmaktadır. Ayrıca şehir merkezinde atıl durumdaki binaların azaltılması potansiyel olarak topluluklara canlılık katarak, suç ve diğer sosyal olmayan davranışları azaltıp yeni yatırımlar ve canlandırma yoluyla bölgenin yaşam standartlarını yükseltmektedir [10]. 
Kullanım dönüşümü ile binaların yaşam döngülerinin de değişime uğramıştır. Binaların yaşam süreçleri kullanım dönüşümü kavramına kadar. Yapı yaşam döngüsü tasarım, yapım, kullanım/işletme ve yıkım olarak ifade edilirken kullanım dönüşümü sonrasında; 1. Tasarım-imalat -kullanım/işletme özgün işlev, 2. Terk edilmeİşlevini kaybetme, 3. Ara-geçici kullanım, 4. Yıkım veya uzun vadeli kullanım (kullanım dönüşümü) şeklinde olduğu düşünülmeye başlamıştır [11].

Bir toplumun sosyal sermayesi toplumu oluşturan bireylerin kültürel birikimi ve sağladıkları insan kaynakları ile ifade edilir. Sosyal sermayeyi oluşturan bireylerin yaşam kalitelerinin belirli bir düzeye taşınması yapılı çevrenin iyileştirilmesi ile mümkün olacaktır. Bir diğer sosyal ölçüt olan topluluk hissinin oluşturulması sosyal sürdürülebilirliğin sağlanmasında önemli bir yere sahiptir. Topluluk hissinin oluşması bireyin kendini güvende hissetmesi ise gelişen aidiyet duygusu, bireyin fikirleri ile topluma katılımı, ihtiyaçlarını karşılayabilmesi ve toplum ile ortak duygular paylaşması ile mümkün olmaktadır [12]. Tarihi yapılar taşıdıkları değerler ve toplumu oluşturan bireyler için ifade ettikleri anlamların ortaklığı bağlamında topluluk hissinin oluşmasında etkilidirler. Atıl durumdaki tarihi yapıların canlandırılarak yeniden kullanılması bireyler arasındaki etkileşimi artırarak bozulan topluluk hissini tekrar oluşturulmasına katk1 sağlar. Tarihi yapı, kenti paylaşan insanların kültürel kimliklerinin bir parçası olduğundan,kullanım dönüşümünde toplumu oluşturan tüm kesimlerin, yeni işlevin ne olacağına karar verilmesi sürecine dâhil edilmesi topluluk hissinin olușturulmasında önemlidir.

Sosyal içerme ve uyum, yoksulların ve dezavantajlı grupların topluma katılmalarının sağlanması sonucu soylulaştırma, dışlanma gibi sorunların önüne geçilmesini hedefleyen sosyal sürdürülebilirlik ölçütüdür [13]. Mevcut yapıları korumak, yaşatmak ve yeniden kullanmak için sebepler çok çeşitlidir. Kullanım dönüşümünün faydaları, yapının maddi olmayan yararlarından toplumsal fayda ve kültürel kimlikten, somut olarak ölçülebilir ekonomik ve çevresel avantajlara kadar uzanmaktadır. Bu bağlamda mevcut bina stokunun potansiyeli ve değeri, sürdürülebilir kalkınmanın bir parçası olarak tanınmalıdır [14]. Tarihi yapılar taşıdıkları kültürel miras değerleri ile sosyal faydalar sağlarlar. Tarihi yapılar otantik sokak manzaralarını koruyabilir, kente karakter ekleyebilir, statü ve kimlik sağlayabilirler [10]. Kullanım dönüşümünde göz önünde bulundurulması gereken bir konu da mevcut yapının en iyi ve doğru şekilde anlaşılmasıdır. Böylece taşıdığı olumlu değerlerin korunması ve yeni işlevin benimsenmesi sağlanabilir [15].

\section{BAĞLARBAŞI ELEKTRIKK FABRIKKASI VE TRAMVAY DEPOSU}

Çalışmanın bu kısmında İstanbul ili Üsküdar ilçesine bağlı Bağlarbaşı semtinde yer alan tarihi özellikler taşıyan ve işlev değişikliğine uğramış bir yapı olan 'Bağlarbaşı Elektrik Fabrikası' ve daha önce aynı arazi üzerinde bulunan 'Tramvay Deposu' tarihsel süreç içerisinde, alan üzerine inşa edilen yeni yapılar ile birlikte geçirdikleri değişim sosyal sürdürülebilirlik bağlamında ele alınmıştır.

\section{1. Üsküdar ve Bağlarbaşı Semti}

İstanbul'un Anadolu yakasında yer alan Üsküdar semti oldukça eski bir yerleşim merkezidir. İstanbul'un fethinden sonra asıl kimliğine sahip olan semt. İmparatorluğun Anadolu ya açılan kapısı konumundaki semt yine aynı yakada bulunan bir diğer önemli yerleşim olan Kadıköy'e olan yakınlığı ile birlikte oldukça merkezi bir yerleşim birimi olmuş günümüzde de metro ağı ve iki kıtayı birbirine bağlayan 'marmaray' tren hattı üzerinde bir transfer noktası olması sebebi ile İstanbul'un önemli merkezlerinden biridir. Üsküdar'n sınırları, kuzeyden Beykoz, kuzeydoğudan Ümraniye, doğudan Ataşehir, güneyden Kadıköy ilçeleri ve batıdan İstanbul Boğazıyla sinırlanmıștır (Şekil 1).

Bağlarbaşı semti de Üsküdar'ın denize komşu olan Mimar Sinan mahallesi ile Kadıköy arasında yer alan, Altunizade mahallesi sınırları içerisinde bulunmaktadır. Bu çalışmaya konu olan ve günümüzde artık kullanılmayan Anadolu yakası tramvaylarının, ana transfer merkezi olarak işlev gören Bağlarbaşı Elektrik Fabrikası ve Tramvay Deposu semtin konumu sebebi ile burada yer almaktadır (Şekil 2). 

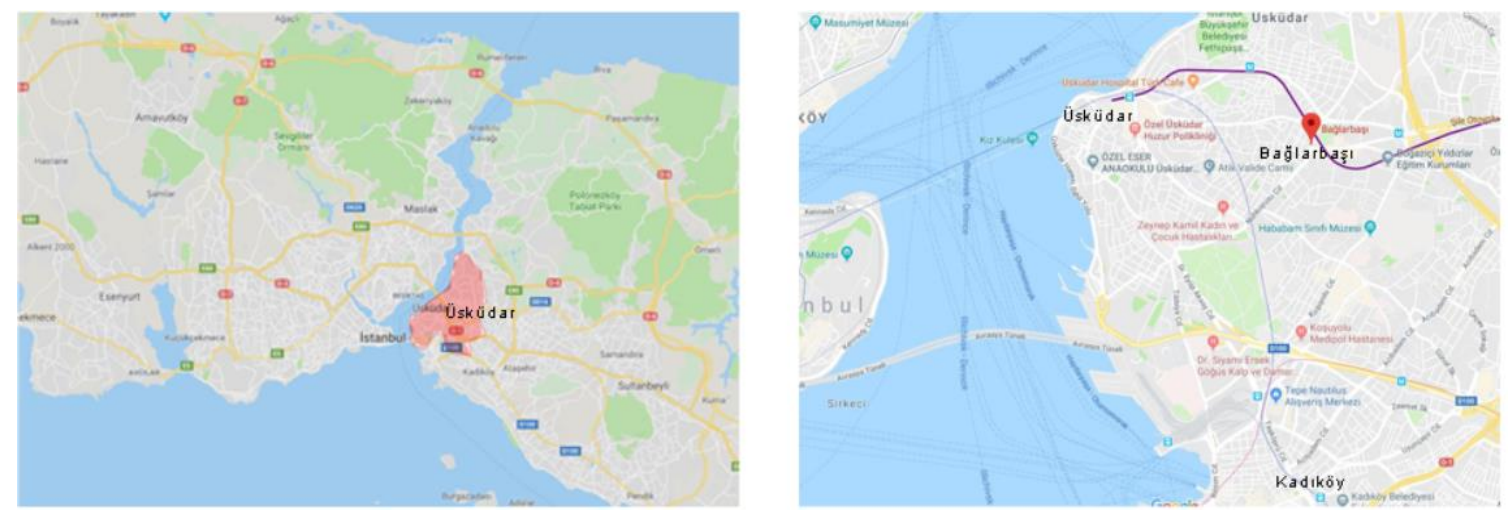

Şekil 1-2. Üsküdar'ın ve Bağlarbaşı semtinin İstanbul'daki konumları [17].

\subsection{Bağlarbașı Elektrik Fabrikası}

Günümüzde kitap kafe olarak kullanılan Bağlarbaşı Elektrik Fabrikası, Bağlarbaşı Meydanı'ndan Selami Ali’ye giderken sağda, bir zamanlar Acıbadem Tekkesi’nin bulunduğu vakıf arazisi üzerinde yer almaktadır. 2015 yılında restore edilerek yeniden işlev kazandırılan tarihi yapı, taşıdı̆̆ı özellikleri ile endüstriyel miras olma özelliği taşımaktadır. Tarihsel süreç içerisinde farklı amaçlarla kullanılan yapının bulunduğu arazide yer alan Tramvay deposu ise yıkılmış, günümüze ulaşamamıştır. Yıkılan depo yerine inşa edilen Bağlarbaşı Kültür Merkezi'nin ve çeşitli işlevleri bir araya getiren Halk Eğitim Merkezi'nin açılışı 2008 yılında gerçekleştirilmiştir. Arazi üzerinde yer alan ve çalışmaya konu olan elektrik fabrikası yapısı 2008-2011 yılları arasında İ.E.T.T. (İstanbul Elektrik Tramvay ve Tünel İşletmeleri ) tarafından 'Ulaşım Müzesi' olarak kullanılmış 2011 yılına gelindiğinde ise yapıyı Üsküdar belediyesine devretmiştir. Belediye tarafından restorasyona alınan yapı 2015 yılına gelindiğinde 'Nevmekan Bağlarbaşı' ismi ile kafe -kütüphane olarak hizmet vermeye başlamıştır (Şekil 3).
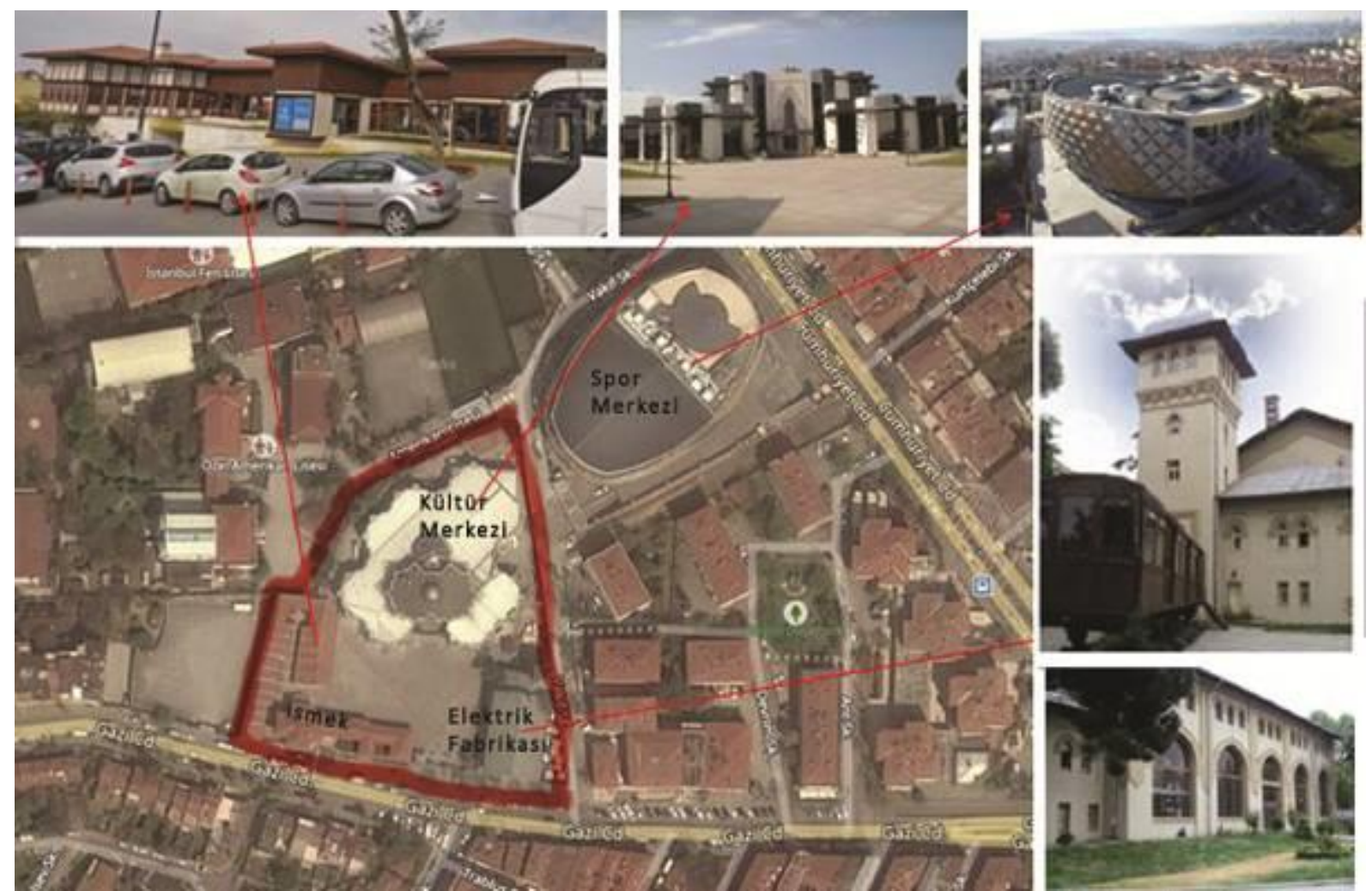

Şekil 3. İstanbul'lun ilçesi Üsküdar'da bulunan Bağlarbaşı Kuvvet Merkezi'nin günümüzdeki kullanımı [17] 
Geçmişte elektrik fabrikası ve tramvay deposunun yer aldığı alanın özgün adı Bağlarbaşı Kuvvet Merkezidir. Elektrik fabrikası ile birlikte Tramvay deposunun ve bekçi kulübesinin yer aldığı yap1 grubunun inşası 1911 yılında Ürgüplü Hayri Bey, tarafından, o zamanki vakıflara ait Alemdağ ormanlarından odun, kömür ve Taşdelen doğal su kaynağından iyi su nakletmek için başlatılmıştır. Bu amaçla Almanya'dan birçok malzeme ile tramvay arabalarını getirip Çamlıca'ya kadar olan rayları döşenmiştir. Ancak 1. dünya savaşı nedeni ile yapımına ara verilmiştir. Daha sonra yapıda bir süre Üsküdar Havagazı Şirketi'ne verilen 'Elektrikle Tenvirat İmtiyazı’ sayesinde elektrik üretilmeye başlanmıştır. 1927 yılında gerçekleştirilen ikinci girişim ile yapının hem elektrik üreten bir fabrika olarak tramvaylara gerekli enerjiyi sağlaması hem de içerisinde yer aldığ geniş arazi ile Tramvay deposu olarak kullanılması amaçlanmıştır. Böylece yapı Üsküdar tramvaylarının hizmete girdiği 7 Haziran 1928 günü törenle açılmıştır [16].

Yapının mimarı 1. ulusal mimarlık akımının temsilcilerinden Mimar Ali Talat Bey (1869-1922)'dir. Mimar Ali Talat Bey Evkaf Nezaretinde Mimar Kemalettin Bey ile çalışmış, Türk yapı sanatını yabancı mimarların etkisinden kurtarmaya çaba göstermiştir [18]. Türkiye'de ekol yaratmış Mimar Kemalettin Bey'le 'Birinci Ulusal Mimari’ akımının öncülügünü yapan Ali Talat Bey, aynı zamanda Beşiktaş (1913), Kuzguncuk ve Üsküdar (1906-yıktırıldı) vapur iskelelerinin mimarıdır. Pervititch tarafından 1930'da hazırlanan plana göre, işletme, geniş iç hacimli bir elektrik fabrikası, fabrikaya geçişi olan iki katlı idare binası ve idare binası ile bağlantılı beş katlı bir kule, bekçi kulübesi ve günümüze ulaşmamış olan tramvay deposundan oluşmaktadır (Şekil 4,5) [19].
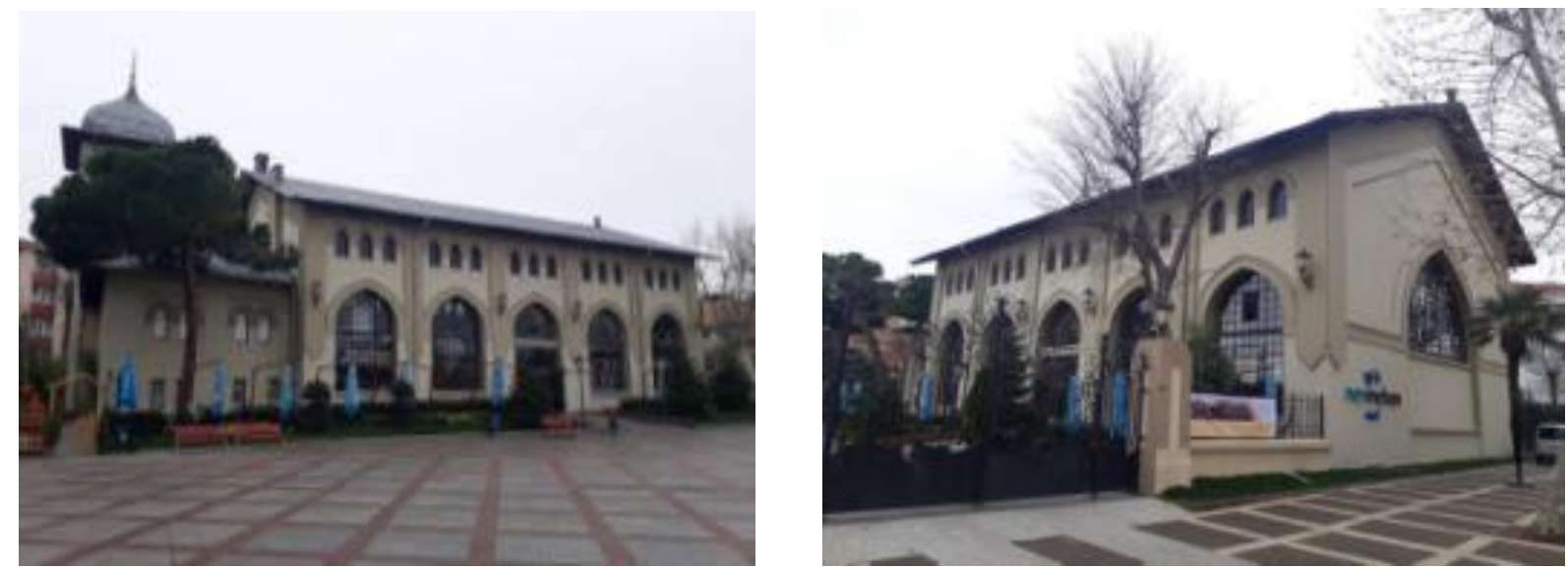

Şekil 4-5. İstanbul'lun ilçesi Üsküdar'da bulunan Bağlarbaşı Elektrik Fabrikası'nın günümüzdeki durumu [20].

Bağlarbaşı Kuvvet Merkezi, Osmanlı döneminin son önemli mimari eserlerinin tasarımında temel olan eklektik bir tavırla neo-klasik tarzda inşa edilmiş, klasik Osmanlı yapılarının mimari unsurlarının kullanıldığı bir yapıdır. İçinde dönemin teknolojisini taşıyan ve trafo kaldırmakta kullanılan hareketli bir vinç bulunmaktadır. Yapı bitişiğindeki kulenin yangın kulesi ve gözlem yeri olarak kullanıldığı sanılmaktadır.

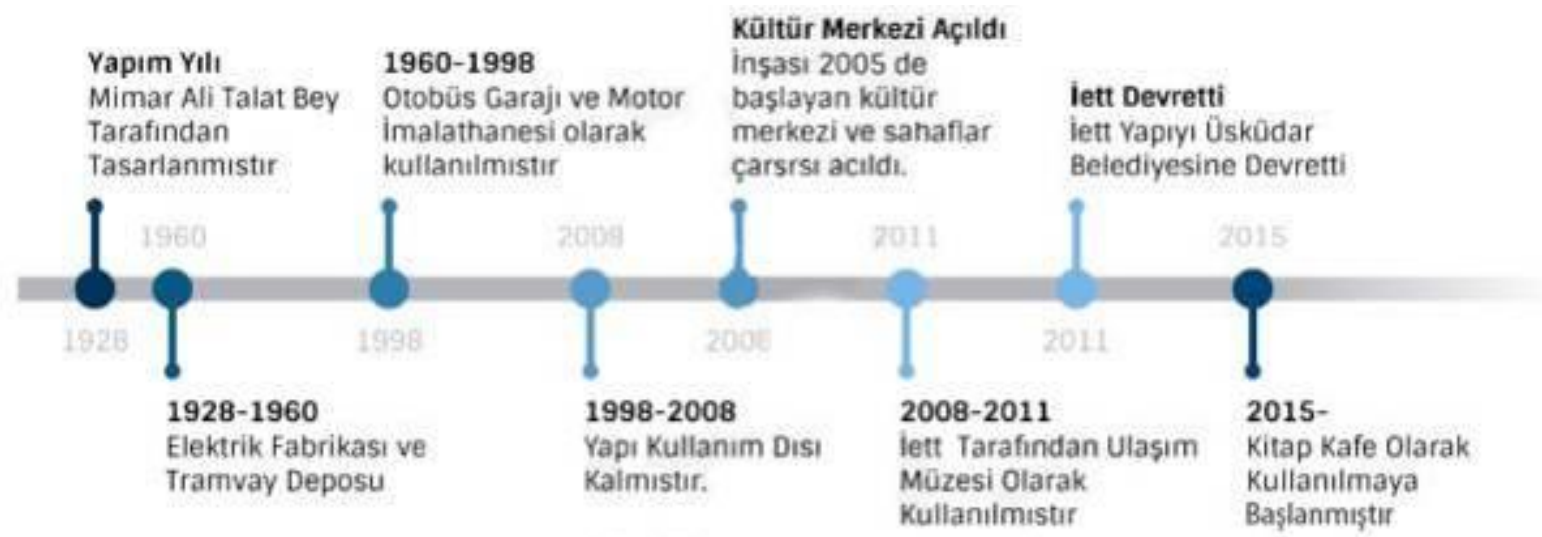

Şekil 6. Bağlarbaşı Elektrik Fabrikası'nın kullanım evreleri.

Elektrik fabrikası ve çevresi, hizmete açıldığı y1l olan 1928'den 1960'ların sonuna kadar tramvay deposu olarak kullanılmıştır. Anadolu yakasından tramvayların kaldırılmasıyla otobüs garajına dönüştürülen alanda bir yandan yüze yakın sayıda otobüs depolanırken diğer yandan üretim atölyesinde motor yapımı, rektifiye ve parça 
imalatı işleri yürütülmüştür. İETT, 1998 yılında İkitelli garajında Motor Yenileme Fabrikası’yla modern tesislere kavuşunca bir süre boş kalan alan daha sonra bölgenin tarihî özelliği dikkate alınarak arazi üzerine kültür merkezine inşa edilmesine karar verilmiştir. İnşaatı 15 Mayıs 2005'te başlayıp 20 Temmuz 2007'de tamamlanan tesisin resmi açılışı 28 Haziran 2008'de yapılmıştır.

İETT'nin kaynaklarıyla yapılan Kültür merkezinde 285 kişilik konferans salonu, 107 kişilik seminer salonu, 94 kişilik cep sinema salonu, 2 adet sergi salonu bulunmaktadır. Halk eğitim merkezi olarak kullanılan ve aynı yıl inşa edilen diğer yapıda ise Türk evi, sahaflr çarşısı, otopark ve kurs derslikleri bulunmaktadır. Elektrik fabrikası ise 2011 yılına kadar ulaşım müzesi olarak hizmet vermiştir [20]. Bağlarbaşı Kongre ve Kültür Merkezi, Halk eğitim merkezi ve Elektrik fabrikası 2011'de İETT Genel Müdürlüğü tarafindan protokolle Üsküdar Belediyesi'ne tahsis edilmiştir.

Tablo 2. Bağlarbaşı Elektrik Fabrikası ve Tramvay Deposunun Güncel Kullanım Durumu

\begin{tabular}{|c|c|c|c|c|c|}
\hline Nitelik & Yapt & Durumu & Ozgin ișler. & Mevcut iglev & Açaklama \\
\hline \multirow{3}{*}{ Tarihi Yapt } & Tramvay Deposu & Vikalmegtar & Depo & $\begin{array}{l}\text { Yapi Yerine Kultür Merkezi } \\
\text { inģa Edilimiştir. }\end{array}$ & \\
\hline & Elektrik Fabrikası & Korunmustur & Elektrik Üretimi & $\begin{array}{l}\text { Bodrum Kat-Depo-Personel } \\
\text { Zemin Kat-Kitap Kafe } \\
\text { Asma Kat-Kafe } \\
\text { Kule-Ofis (Gonullo } \\
\text { Merkezi,Tasanm Ofisi) }\end{array}$ & 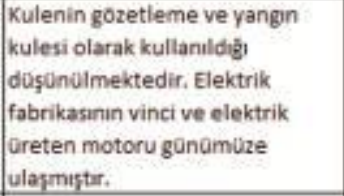 \\
\hline & Bekçi Kulubesi & Korunmuştur & Bekçi Kulubesi & Givenlik & \\
\hline \multirow[t]{2}{*}{ Yeni Yapi } & Bağlarbasa Kütur Merkezi (2003) & Meveut & Kültür Merkezi & Kültür Merkezi & $\begin{array}{l}285 \text { kiģilik konferans salonu, } 107 \\
\text { kişilik seminer salonu, } 94 \text { kişilik } \\
\text { cep sinema salonu, } 2 \text { adet sergi } \\
\text { salonu bulunmaktadir. }\end{array}$ \\
\hline & Ismek-Halk Egitim Merkezi (2008) & Mevcut & Halk Egjitim Merkezi & Halk Ek̉itim Merkezi & $\begin{array}{l}\text { Turkevi, sahaflar çargsi, otopark } \\
\text { ve kurs derslikleri bulunmaktadir }\end{array}$ \\
\hline
\end{tabular}

Kullanım hakkının İETT tarafından Üsküdar Belediyesine verilmesinin ardından, kısa süre içerisinde restorasyon çalışmalarının başlatıldığı yapı yeniden işlev verilerek 2015 yılında hizmete açılmıştır. Yapının zemin katı ve asma katı kafeterya ve kütüphane olarak kullanılmaktadır. Yapının kütüphanesinde farklı türlerde yaklaşık 10.000 kitap bulunmaktadır. Yapıya ait kule ve bitişiğindeki bölümde ise Üsküdar belediyesi ile ortaklaşa faaliyet gösteren yardımlaşma ve paylaşma odaklı bir birim olan "Gönüllü Merkezi", "Bir İyilik Yap Dükkânı" ve "Tasarım Stüdyosu" gibi Üsküdar birimler yer almaktadır (Şekil 8,9,10) .
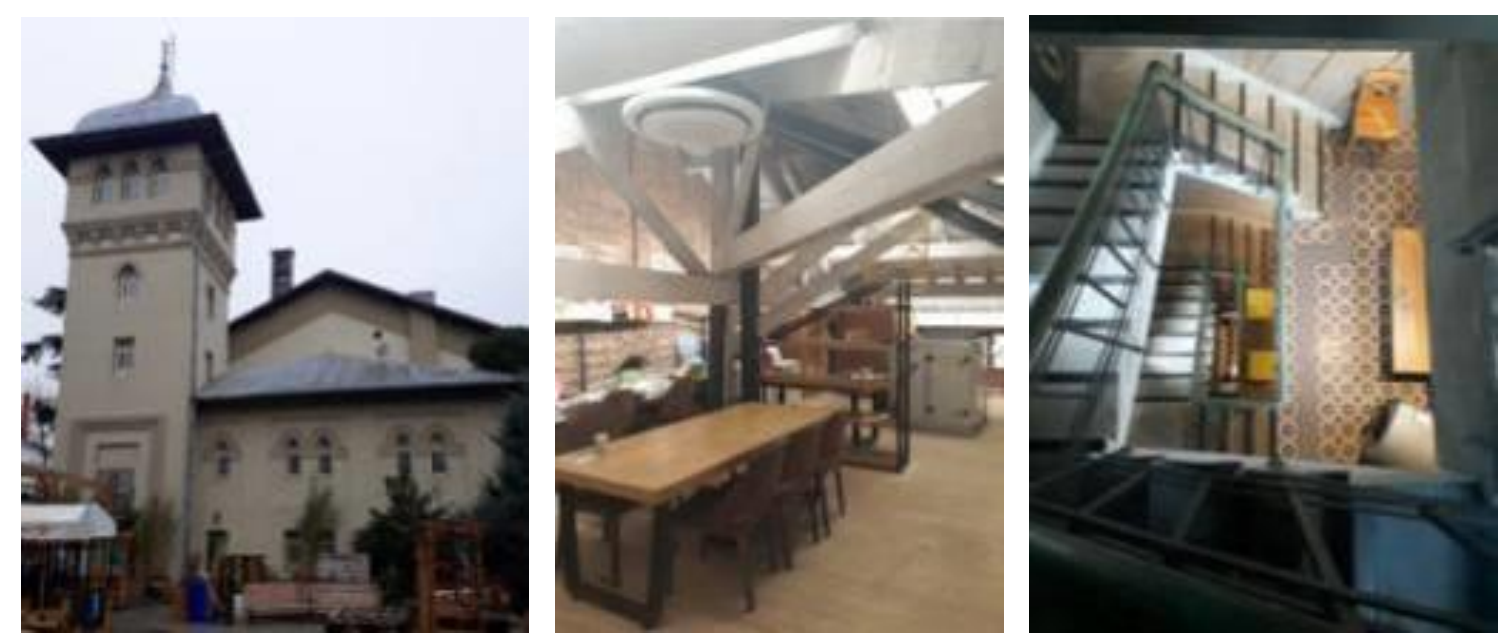

Şekil 8-9-10. Gönüllü Merkezi ve Kule içerisinden görünümler [20] 


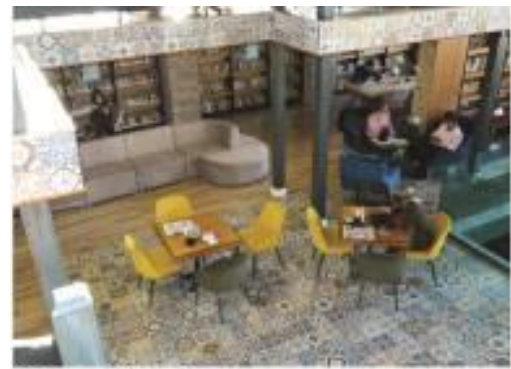

1-Asma Kattan Bakış

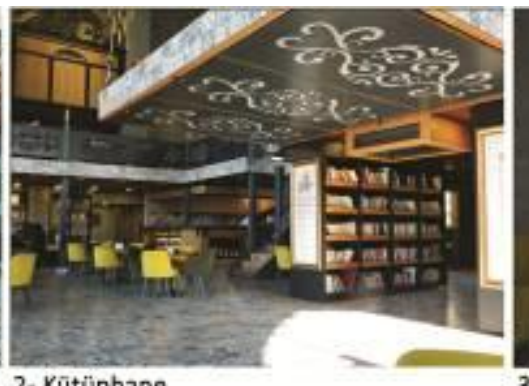

2- Kūtüphane
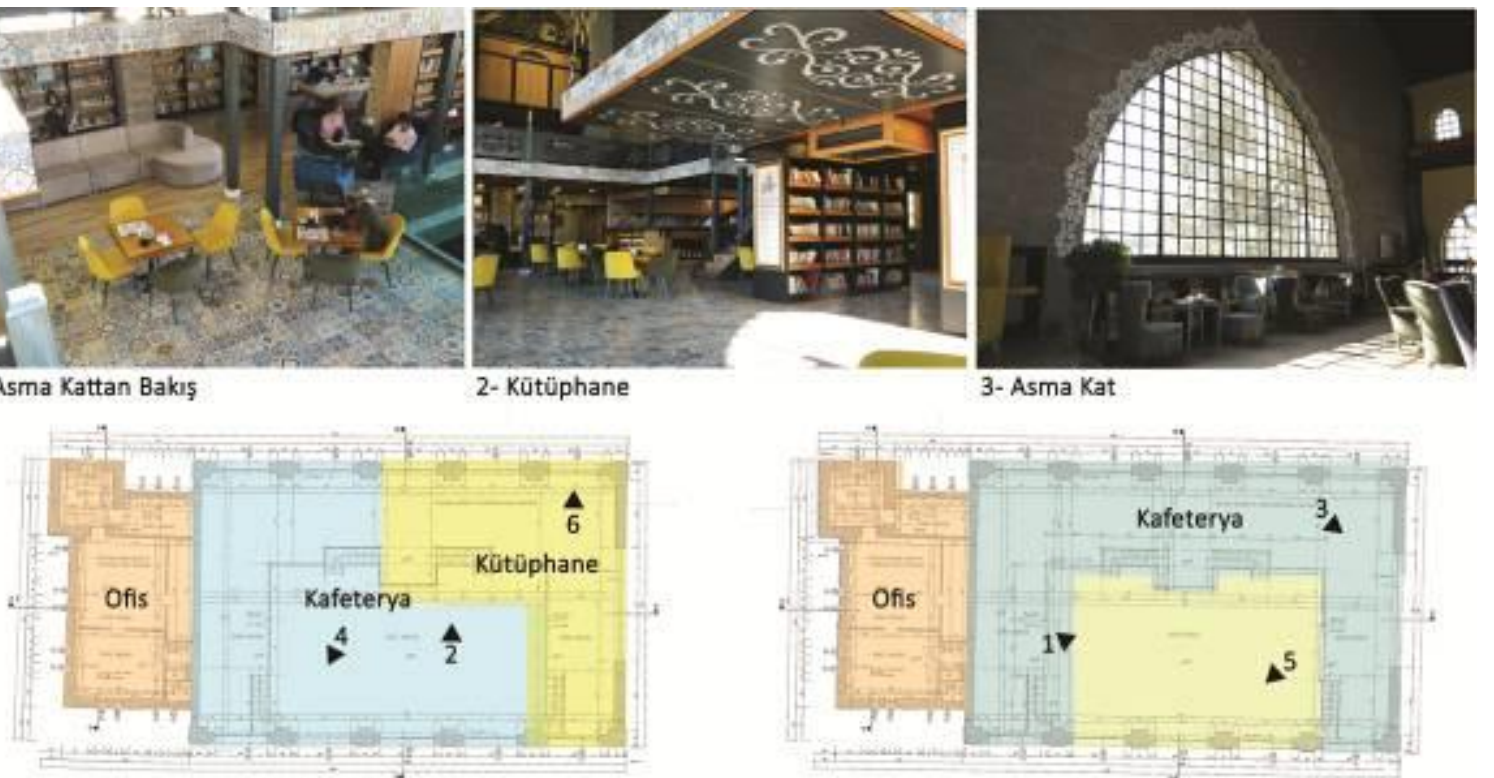

Zemin Kat Planı

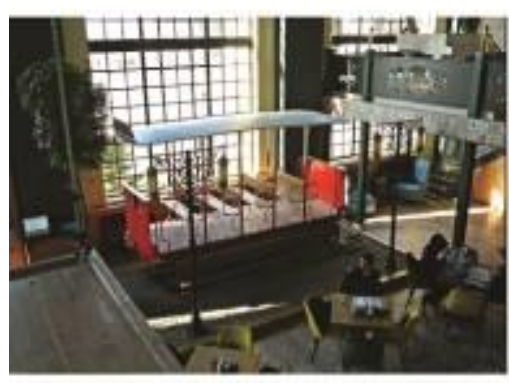

4-Tramvay Vagonu

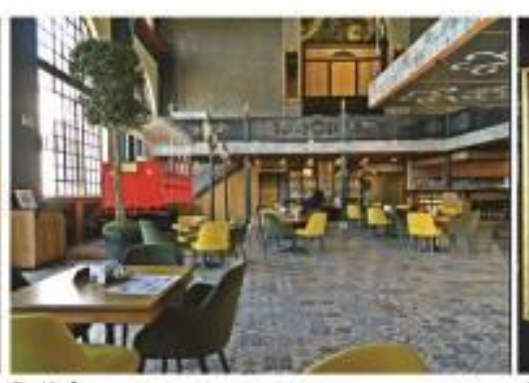

5- Kafeterya

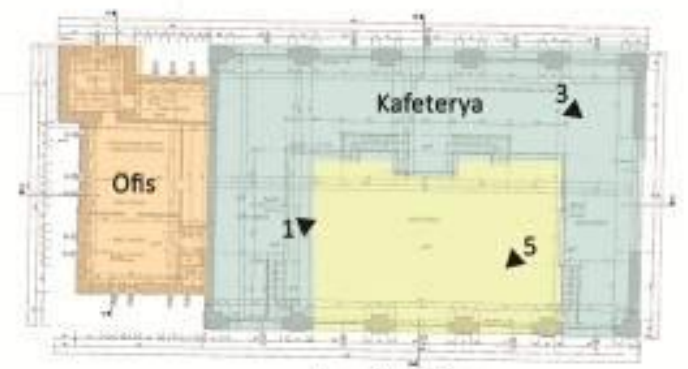

Asma Kat Planı

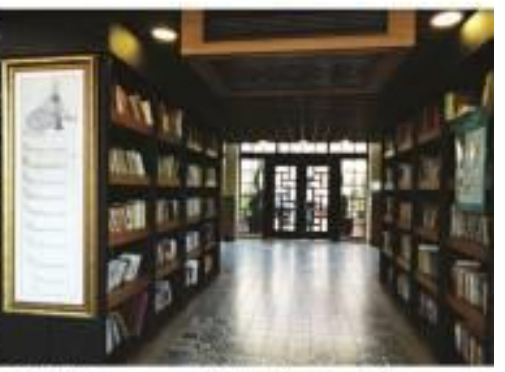

6- Kotüphane ve Arka Bahçeye Çıkıs

Şekil 11. Bağlarbaşı Elektrik Fabrikası Planları ${ }^{1}$ ve Verilen İşlevler. Fotoğraflar [22]

Yapının bitişiğindeyer alan bekçi kulübesi aynı işlev ile kullanılmaya devam etmektedir. Yapı günümüzde 'Gönüllü Merkezi' ve 'Bir İyilik Yap Dükkânı ve Tasarım Stüdyosu' ile çeşitli sosyal aktivitelere, sergi, kermes gibi etkinliklere ev sahipliği yaparak farklı kesimden insanları bir araya getirmektedir. Yapının kitap kafeterya kısmı da kapalı, açık ve yarı açık mekânları ile sadece Üsküdarlıların değil tüm İstanbul halkının ziyaret ettiği bir çekim noktası olmuştur.

Bodrum kat, Zemin kat ve gözetleme amaçlı kullanıldığı düşünülen kuleden oluşan yapının, trafoları kaldırmakta kullanılan 10 ton kapasiteli vinci ve elektrik üretiminde kullanılan dizel motor günümüze ulaşmıştır. Çeşitli kültürel etkinliklerin, söyleşilerin ve konserlerin gerçekleştirildiği yap1 belediye tarafından işletilmektedir. Yapının Zemin katı kafeterya ve kütüphane olarak kullanılmaktadır. Sonradan eklenen asma katı da yine kafeterya olarak hizmet vermektedir.

Kafeterya bölümüne yerleştirilen tramvay vagonu ile yapının özgün işlevinin kullanıcılara hatırlatılması amaçlanmıştır.Yapı içerisinde sergilenen tramvay vagonu 'Beşiktaş-Karaköy' hattı üzerinde bir süre kullanılmış ve günümüze ulaşan yazlık vagonlardan birisidir.Sadece yaz aylarında kullanılan bu havadar vagonların Üsküdar halkı tarafından kısa sürede benimsendiği bilinmektedir. Anadolu yakasında hizmet veren tramvaylar Avrupa yakasındakilerin aksine IEETT tarafindan değil özel bir şirket olan Üsküdar-Kadıköy ve Havalisi Halk Tramvayları Şirketi (ÜKHT) tarafından işletilmekteydi. Anadolu yakasında hizmet veren tramvayların vagonları ise Avrupa yakasındaki vagonlar gibi kırmızı değil sarı veya açık yeşil renkteydi. [23]

\footnotetext{
${ }^{1}$ Üsküdar belediyesinden temin edilen Bağlarbaşı Elektrik Fabrikası'na ait planlardan türetilmiştir.
} 


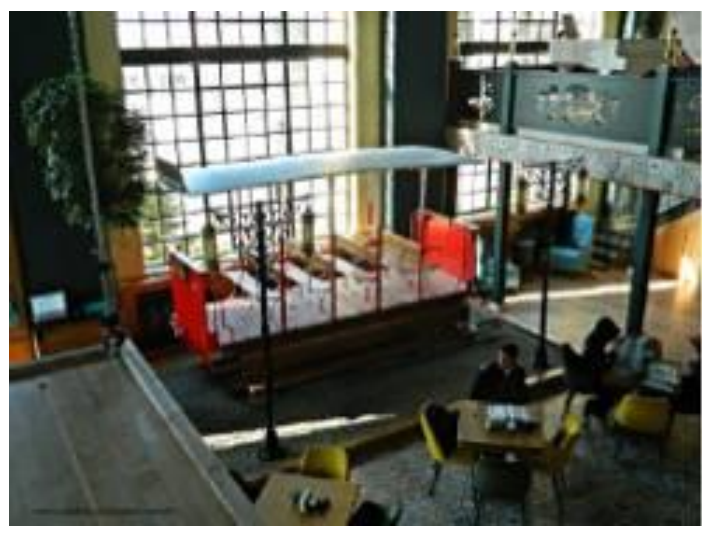

Şekil 12. Yapı içerisinde sergilenen tramvay vagonu [22].

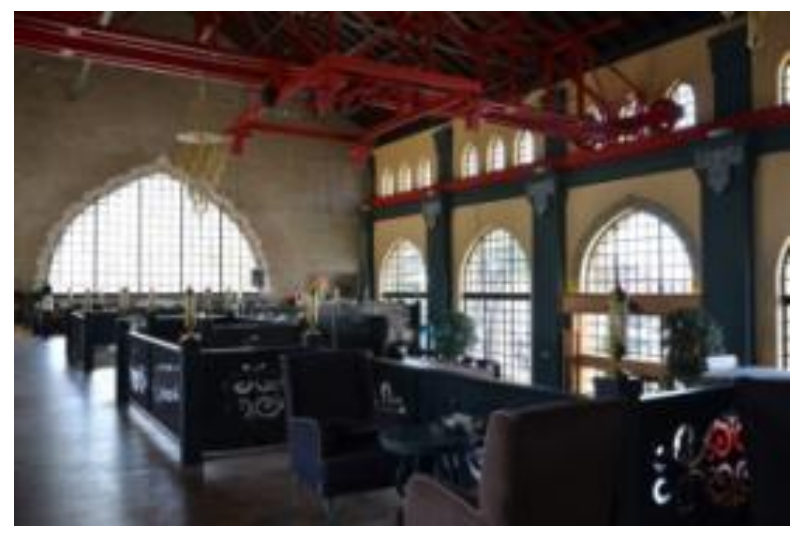

Şekil 13. Yapı içerisinde özgün işlevinden günümüze ulaşmış vinç [24].

Yapının iki ayrı merdiven yardımı ile inilen bodrum katında ise wc personel odaları gibi servis birimlerinin yanı sıra sergi salonu yer almaktadır. Sergi salonunda çeşitli sanatçılar tarafından geçici sergiler açılmaktadır.

Restorasyon ve kullanım dönüşümü sırasında yapıya asma kat eklenmiştir. Vinç bu asma kata bağlanan ve sahne işlevi gören platformu taşıyacak ve gerektiğinde hareket ettirecek şekilde korunmuştur. Vinç yardımı ile sahne istenilen konuma getirilebilmesi sayesinde söyleşi, imza günü, müzik dinletisi gibi farklı etkinliklerin gerçekleştirilebilmesi için gerekli ortam sağlanabilmektedir. Elektrik üretiminde kullanılan motor ise kafeteryanın açık kullanım alanı olarak kullanılan arka bahçede koruma altına alınmış olarak sergilenmektedir.

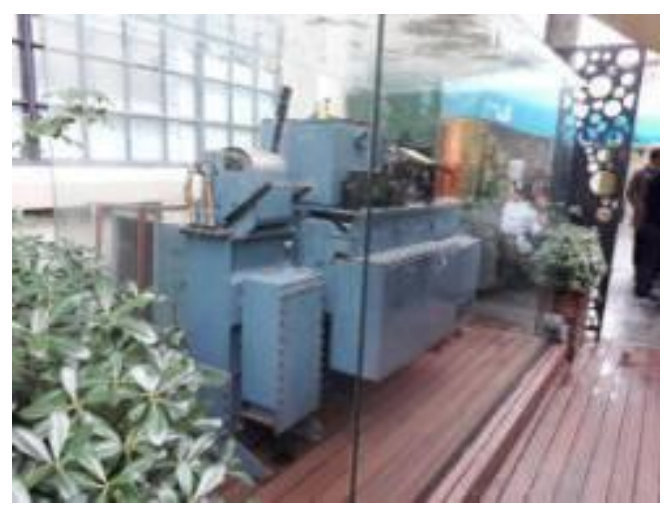

Şekil 14. Elektrik üretiminde kullanılan motor [20]. 


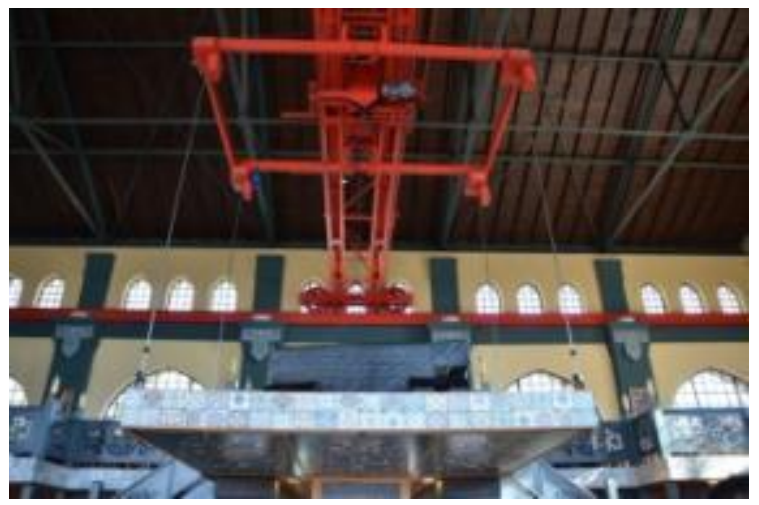

Şekil 15. Yapı içerisindeki vinç ve taşıdı̆̆ı sahne [24].

\section{DEĞERLENDİRME VE SONUÇ}

Değerlendirme bölümünde İstanbul'un Anadolu yakasında yer alan Üsküdar ilçesi sınırları içerisindeki Bağlarbaşı semtindeki, Bağlarbaşı Elektrik Fabrikası ve Tramvay deposunda gerçekleştirilen kullanım dönüşümü yapılan gözlemler, kullanıcılardan ve Üsküdar belediyesinin ilgili birimlerinden yetkililer ile yapılan görüşmeler yardımı ile çalışmada çizilen kavramsal çerçeve bağlamında tartışılmıştır. Sonuç bölümünde ise bu örnekten yola çıkılarak gelecekte tarihi yapılarda gerçekleştirilecek kullanım dönüşümü uygulamaları için yol gösterici olacağı düşünülen çıkarımlar yapılmıştır.

\subsection{Değerlendirme}

Daha önce tablo 1'de sosyal sürdürülebilirlik literatüründen yeniden kullanım ile ilişkili olduğu düşünülen ölçütler derlenmişti. Tabloda kullanım dönüşümünün boyutuna göre, Bellek, Kimlik, Aidiyet, Yaşam Kalitesi, Mekân Hissi, Fiziksel ve Psikolojik Konfor, Adalet, Eşitlik, Katılım, Çevresel Kalite, Sosyal Fayda, Topluluk Hissi ölçütlerinin sosyokültürel sürdürülebilirlik üzerinde olumlu etki yapacağı belirtilmişti. Çalışmanın bu bölümünde yapı ve yakın çevresi üzerine yapılan analizler ile ilk aşamada belirlenen ölçütlerin yerine getirilip getirilmediği tartışılmıştır. Ölçütlerin ne ölçüde yerine getirildiği kullanım dönüşümünün boyutunu ifade eden üç önemli aktörün yani Kent ve Kentli, Dönüştürülen Yap1 ve Yapıya Verilen Yeni İşlev 'in kullanım dönüşümünden nasıl etkilendiği üzerinden yapılmıştır.

\subsubsection{Mevcut Yapı ve Sosyo-Kültürel Sürdürülebilirlik}

Bağlarbaşı Elektrik Fabrikası'nın zamanda dondurularak korunması yerine yeni bir işleve adapte edilerek kullanılması ve yaşamaya devam etmesinin sağlanması, tanıklık ettiği dönemi yansıtması ve kentsel belleği günümüze taşıması yönleriyle olumlu bir uygulamadır. Yapının kullanım dönüşümü sırasında cephe ve malzeme özellikleri gibi kimliğini yansıtan özellikleri korunmuştur. Yapıda sergilenen tramvay vagonu, elektrik üretiminde kullanılan motor ve tasarıma dâhil edilerek çalışır durumda yeni işleve uyarlanarak korunan vinç, yapının özgün işlevini kullanıcılarına anımsatmaktadır. Yapının özgün özelliklerinin korunmasına karşın çoğu kullanıcının yapının özgün işlevi hakkında fikir sahibi olmadığı gözlemlenmiştir. Bu durum yapı içerisinde yapının geçirdiği dönüşümü anlatan herhangi bir bilgilendirici pano veya posterin olmayışına ve alanda yer alan tramvay raylarının artık bulunmayışına bağlanmıştır. Bunda yapının özgün işlevine referans verecek, herhangi bir donanım, donatı veya izin (eskimişlik vb.) bulunmayışı da önemli bir etkendir.

\subsubsection{Yeni İşlev ve Sosyo-Kültürel Sürdürülebilirlik}

Tarihi yapıların korunması kadar önemli bir konu da yapının topluma dâhil olan tüm bireyler tarafından erişilebilir bir şekilde yaşatılmasıdır. Bu bağlamda yapıya kafeterya ve kütüphane gibi herkesin kolayca faydalanabileceği bir işlevin verilmesi eşitlik, adalet gibi sosyal sürdürülebilirlik ölçütleri bağlamında olumludur. Yapı arazisine inşa edilen kültür merkezi ve halk eğitim merkezi de bu amaca katkı sağlamış bu üç yapı ve açık alanlarının sağladığı avantaj ile Üsküdar için bir kültür odağı oluşturulması mümkün olmuştur. Ancak 2008 yılında, artık mevcut olmayan Tramvay Deposu yerine inşa edilen Kültür Merkezi, Elektrik fabrikasının yaklaşık altı katı büyüklüğünde bir oturum alanına sahiptir. Yapının oldukça büyük bir kütle oluşu, cephe ve kütle tasarımının bulunduğu yerden kopuk olması bu etkiyi zayıflatmıştır (Şekil 1). Alana sonradan inşa edilen bu 
yapılar tarihi yapı ile mimari bir birlik oluşturmadığı gibi kendi aralarında da tasarımsal bir bütünlük göstermemektedir. Mekânsal kalite ve yeterlilik açısından ele alındığında ise yapının yeni işlevin gerektirdiği tüm birimleri karşıladığı, fiziksel ve psikolojik olarak konforlu olduğu söylenebilir.

\subsubsection{Kent- Kentli ve Sosyo-Kültürel Sürdürülebilirlik}

Yapının yer aldığı Selami Ali mahallesinin sosyo-ekonomik olarak iyi bir tablo çizmediği göz önüne alındığında Gönüllü Merkezi gibi bir sosyal dayanışma oluşumunun burada yer alması mahallenin sorunlarına çözüm bulunabilmesi açısından olumlu olmuştur. Kafeteryanın belediye tarafından işletilmesi verilen hizmetlerin kentin farklı kesimleri tarafından karşılanabilir olmasını sağlamıştır. Bu durum aynı zamanda Üsküdar Belediyesi kar amacı gütmeyen etkinliklerin düzenlenebileceği bir mekâna sahip olmasını sağlamıştır. Yapı arazisine inşa edilen halk eğitim merkezi de verdiği kurslar, düzenlediği kermesler ve sağladığı imkânlar ile toplumsal gelişmeye katkı sağlamaktadır. Üsküdar merkezine oldukça yakın bir konumda yer alan yapı etki alanındaki insanlar için bir sosyalleşme mekânı sunarken yakın çevresinin fiziksel kalitesine de katkı sağlamıştır. Bağlarbaşı Elektrik Fabrikası ve Tramvay Deposunun kullanım dönüşümü yapı yakın çevresindeki üniversite öğrencilerinin ve mahalle sakinlerinin bir araya gelmesini sağlarken bulunduğu kent parçasının da fiziksel olarak iyileşmesine katkı sağlamıştır. Atıl bir halde iken iyileştirilen yapı sokak slüetini zenginleştirirken, açık ve yarı açık alanlarının insanlar tarafından aktif olarak kullanılması yapı yakın çevresine canlılık getirmiştir. Yapı yakın çevresinde Marmara Üniversitesi, Üsküdar Üniversitesi ve İstanbul 29 Mayıs Üniversitesinin yanı sıra lise ve ilkokul düzeyinde eğitim kurumları yer almaktadır. Yapı ile aynı arazi üzerinde kültür merkezi ve halkı eğitim merkezinin bulunması, bitişiğindeki ada üzerinde de spor merkezinin bulunması. Kitap-Kafe işlevi verilen Bağlarbașı elektrik fabrikasının özellikle gençler tarafından kullanılan bir mekan olușu bölgeyi bir odak haline dönüştürmüştür ve kültür merkezi ile halk eğitim merkezinin bulunduğu kent parçasının işlerliğine katk1 sağlamıştır.

Yapıya ilişkin değerlendirmeler Şekil 16'da görselleştirilmiştir. Buna göre dönüştürülen yapının özgün işlevinin kullanıcıya hatırlatılması, yeni işlevler belirlenirken kullanıcı katılımının sağlanmaması ve yapının asma katına ve bodrum katına engelli bireylerin erişimlerinde zorlukların yaşanması, asansörün bulunmaması gerçekleştirilen kullanım dönüşümünün en zayıf noktaları olarak belirlenmiştir. Buna karşın tarihi yapının tüm yaş gruplarına hitap eden yeni bir işlevle yüklenmesi, sosyal fayda sağlaması ve çevresel kaliteyi artırması açısından kent ve kentli için olumlu bir yaklaşım olarak değerlendirilmiştir.

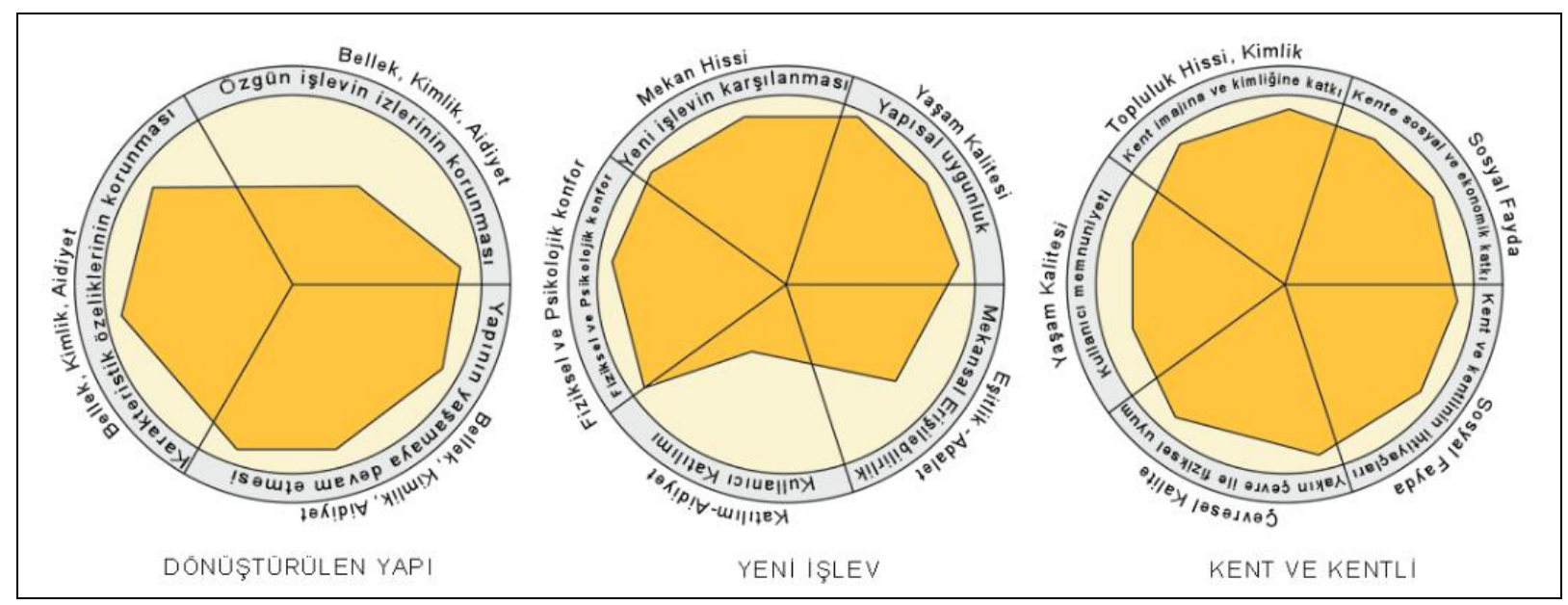

Şekil 16: Yapıya uygulanan kullanım dönüşümünün sosyo-kültürel sürdürülebilirlik bağlamında değerlendirilmesi.

\section{SONUÇ}

$\mathrm{Bu}$ çalışmada taşıdığı özellikleri ile topluma değer katma ve bulunduğu kent parçasının kimliğini yansıtma gibi faydalar sağlayacağı düşünülen, istanbul'un Üsküdar ilçesi sınırları içerisinde yer alan Bağlarbaşı semtinde bulunan Bağlarbaşı Elektrik Fabrikası ve Tramvay Deposu'nun kullanım dönüşümü sosyo-kültürel sürdürülebilirlik bağlamında ele alınmıştır. Çalışmada yapının yeniden kullanımı; literatür araştırması ile tespit edilen Bellek, Kimlik, Aidiyet, Yaşam Kalitesi, Mekân Hissi, Fiziksel ve Psikolojik Konfor, Adalet, Eşitlik, 
Katılım, Çevresel Kalitenin sağlanması, Sosyal Fayda ve Topluluk Hissi gibi sosyal ve kültürel olarak sürdürülebilirliğin sağlanmasına ölçüt olabilecek kavramlar üzerinden değerlendirilmiş̧ir. Gözlem ve tespitlere dayanan değerlendirme kullanım dönüşümü uygulamasının üç önemli aktörü olarak belirlenen "Dönüştürülen Yapı", "Yeni İşlev" ve "Kent ve Kentli" perspektifinden ele alınmıştır.

İncelenen bu örnekten gelecekteki yapılacak kullanım dönüşümü projelerinde göz önünde bulundurulması gereken bazı çıkarımlar yapılabilir;

Tarihi yapılar korunması gerekli kültür varlıklarıdır. Tarihi yapılarda kullanım dönüşümü çevresel, sosyal ve ekonomik olarak birçok fayda sağlamaktadır. Kullanım dönüşümü ile enerji korunumu sağlanırken yapı çevresinin fiziksel, sosyal ve kültürel olarak da iyileştirilmesi mümkün olmaktadır. Tarihi yapıların çoğunun katma değeri yüksek şehir merkezinde yer aldığı göz önüne alındığında rant oluşumunun önüne geçmek ve yapıdan toplumun tüm katmanlarının faydalanmasını sağlamak üzere yapıya kamu yararına bir fonksiyon verilmesi ve kamu tarafindan işletilmesi uygun olacaktır.

Kullanım dönüşümü uygulamaları çoğu zaman maliyeti yüksek, çeşitli teknik ve yasal sorunların yaşandığı süreçlerdir. Bu nedenle yapının yeni işlevinin ne olacağı, yapı yakın çevresinin nasıl ele alınacağı titizlikle analiz edilmelidir. Kullanım dönüşümü uygulamalarında geri dönüş yapılması zor yapının strüktürü ve cephesi gibi fiziksel özellikleri üzerinde yapılan hataların düzeltilmesi yüksek maliyetlidir.

Tarihi yapıların taşıdıkları olumlu değerlerin korunması ve yeniden toplumun ihtiyaçlarına cevap verebilecek şekilde kullanılması, kente karakter ekleyecek, geçmişi ile bağlarının devam ettiğini gören kullanıcılarda da aidiyet duygusunun oluşmasını sağlayacaktır. Bu bağlamda tarihi yapıların sağladıkları toplumsal faydalar ölçülebilir çevresel ve ekonomik faydalarından çok daha fazladır.

Üsküdar belediyesi gerçekleştirdiği bu dönüşüm ile ilçede önemli bir eksikliği gidermiş, farklı kesimden insanların bir araya gelip sosyalleşebilecekleri, mimari değeri yüksek bir mekân elde etmiştir. Belediye olumlu geri dönüşler üzerine Üsküdar sahilinde bulunan eski evlendirme dairesi binasını da benzer bir konsepte kitapkafeterya olacak şekilde yeniden işlev kazandırmıştır.

\section{KAYNAKLAR}

[1] JOHN A. KILPATRICK "Adaptive Re-Use of Brownfields: A Challenge for the Valuation" http://www.rics.org/Environmentalandlandconsultancy/Environmentalmanagement/Val_1005.html (Erişim tarihi 24.02.2019)

[2] LATHAM, D., Creative Re-Use of Buildings, Donhead Publishing Ltd, Shaftesbury,2000

[3] YÜKSEK M. "Sürdürülebilir Kalkınma ve Türkiye'de Çevre Politikaları", Gaziantep Üniversitesi Yüksek Lisans Tezi, 2010

[4] BULLEN, P. A. ,"Adaptive reuse and sustainability of commercial buildings", Facilities, Vol. 25 Iss1/2 pp. $20-31,2007$

[5] BULLEN, P. A., Sustainable Adaptive Reuse Of The Existing Building Stock İn Western Australia. In: Khosrowshahi, F (Ed.), 20th Annual ARCOM Conference, 1-3 September 2004, Heriot Watt University. Association of Researchers in Construction Management, Vol. 2, 1387-97. 2004

[6] ARABACIOĞLU, P. , AYDEMIR, I., "Tarihi Çevrelerde YenidenDeğerlendirme Kavramı", YTÜ Mim. Fak. E Dergisi, Cilt: 2, Sayı: 4,Türkiye, 204-212, 2007.

[7] AKSOYA, E., AYDIN, D. "Mimaride Yeniden Kullanım: Sürdürülebilirlik Bağlamında Raziye Takkalı Evinin Yeniden Kullanımı İçin Mekansal Analizler" 2 nd International Sustainable Buildings Symposium, Ankara, 2015

[8] GÜNÇE, K., MİIIRLISOY, D., Questioning the Adaptive Reuse of Industrial Heritage and Its Interventions in the Context of Sustainability, Sociology Study, September 2015, Vol. 5, No. 9, 718-727

[9] TAŞTAN, H. 'Yapılı Çevrede Sosyal Sürdürülebilirlik Bağlamında Kullanıcı Katılımı' Yıldız Teknik Üniversitesi, Fen Bilimleri Enstitüsü, Yüksek Lisans Tezi, 2016-İstanbul

[10] LANGSTON, CRAİG\&WONG, FRANCIS \& C.M. HUI, EDDIE\&SHEN, LIYİN., Strategic Assessment Of Building Adaptive Reuse Opportunities İn Hong Kong. Building And Environment. 43. 1709-1718. 10.1016/j.buildenv.2007.10.017. , 2008

[11] GRAVAGNUOLO, A., ANGRISANO, M. AND FUSCO GIRARD, L. ,Circular Economy Strategies in Eight Historic Port Cities: Criteria and Indicators Towards a Circular City Assessment Framework. Sustainability, 11(13), p.3512., 2019.

[12] NIROUM, SHISHAVAN, SOGHRA., Comparative Investigating Of Adaptive Reuse and Sustainable Architecture with Social Approach., AlamCipta. 6(2). 101-111., 2013 
[13] YUNG,E.,CHAN,E., XU,Y. Community-Initiated Adaptive Reuse of Historic Buildings and Sustainable Development in the Inner City of Shanghai. Journal of Urban Planning and Development, 140(3), p.05014003., 2014.

[14] ORBASLI, A. "Re-Using Existing Buildings Towards Sustainable Regeneration" School of Architecture: Place Culture \& Identity Group working paper, Oxford Brookes University, 2009

[15] ELSORADY, D., Assessment Of The Compatibility Of New Uses For Heritage Buildings: The Example Of Alexandria National Museum, Alexandria, Egypt. Journal of CulturalHeritage, 15(5), pp.511-521. , 2014.

[16]EVREN, G. "İstanbul Ulaştırmasının Dünü, Bugünü" Türkiye Mühendislik Haberleri Dergisi Sayı 413 2001/3

[17] https://www.google.com/maps/dir//Selami+Ali+Mh.,+Üsküdar+Belediyesi+Bağlarbaşı+Kongre+ve+Kültür +Merkezi , (Erişim tarihi 24.02.2019)

[18] KURTOĞLU, A., "Üsküdar Şehiriçi Ulaşım Tarihi" 7.Uluslararası Üsküdar Sempozyumu, İstanbul, 2012

[19]KÖKSAL, G., İstanbul' daki Endüstri Mirası İçin Koruma ve Yeniden Kullanım Önerileri, Doktora Tezi, İTÜ Fen Bilimleri Enstitüsü, İstanbul.,2005

[20] TAŞTAN, H., Kişisel Fotoğraf Arşivi

[21] http://www.yoldakiizler.com/2015/11/nevmekan-cafe-uskudar-kultur-merkezi.html., ～(Erişim tarihi 24.02.2019)

[22] http://defnenil.blogspot.com.tr/2015/11/nevmekan-beni-burada-unutun.html (Erişim tarihi: 09.04. 2018)

[23] http://www.doganhasol.net/uskudar-anilari.html., (Erişim tarihi 24.02.2019)

[24] http://www.yoldakiizler.com/2015/11/nevmekan-cafe-uskudar-kultur-merkezi.html. (Erişim tarihi: 09.04 2018) 